\title{
Changes in xylosyltransferase activity and in proteoglycan deposition in bleomycin-induced lung injury in rat
}

\author{
R. Koslowski*, U. Pfeil*, H. Fehrenbach", M. Kasper ${ }^{\star}$, E. Skutelsky ${ }^{+}$, K-W. Wenzel*
}

Changes in xylosyltransferase activity and in proteoglycan deposition in bleomycininduced lung injury in rat. R. Koslowski, U. Pfeil, H. Fehrenbach, M. Kasper, E. Skutelsky, K-W. Wenzel. (C) ERS Journals Ltd 2001.

ABSTRACT: Several lines of evidence support the hypothesis of the involvement of altered proteoglycan deposition in the development of lung diseases. UDP-D-xylose: core protein $\beta$-D-xylosyltransferase (UDP-xylosyltransferase; EC 2.4.2.26) is a key enzyme for the glycosylation of proteoglycan core proteins. This study examined the catalytic activity of UDP-xylosyltransferase in lung tissue and in isolated fibroblasts, as well as the deposition of the proteoglycans versican, biglycan and decorin in rat lung tissue during bleomycin-induced lung injury.

Rats were given, endotracheally, a single dose of bleomycin. Deposition of proteoglycans in lung tissue was assessed by immunohistochemistry and the catalytic activity of xylosyltransferase was determined with an acceptor peptide of the sequence Q-E-E-E-G-S-G-G-G-Q-G-G as a substrate.

The results show coincidence of increasing xylosyltransferase activities in lung tissue with accumulation of versican at alveolar entrance rings and in fibrotic regions in close proximity to $\alpha$-smooth muscle actin-positive cells. In contrast, no changes in biglycan and decorin deposition in fibrotic lungs were observed, except for decorin in alveolar type II pneumocytes and alveolar macrophages. Bleomycin treatment of isolated rat lung fibroblasts resulted in a concentration-dependent increase of xylosyltransferase activity up to $2 \mathrm{mU}$ bleomycin $\cdot \mathrm{mL}^{-1}$.

The data suggest a participation of myofibroblasts with increased xylosyltransferase activities in accumulation of versican in fibrotic foci of injured lung tissue at the early stages of development of lung fibrosis.

Eur Respir J 2001; 18: 347-356.
Institutes of *Physiological Chemistry, "Pathology and Anatomy, Dresden University of Technology, Dresden, Germany. ${ }^{+}$Dept of Pathology, Sackler Medical School, Tel-Aviv University, Israel.

Correspondence: R. Koslowski, Institute of Physiological Chemistry, Medical Faculty Carl Gustav Carus, Dresden University of Technology, Fiedlerstr. 42, D-01307 Dresden, Germany. Fax: 493514586305

Keywords: Lung fibrosis

myofibroblast

proteoglycans

xylosyltransferase

Received: September 282000

Accepted after revision March 292001

This work was supported by the Bundesministerium für Bildung und Forschung, Germany (FKZ 01ZZ5904).
Pulmonary fibrosis develops in response to lung injuries caused by either radiation, chemical agents or pulmonary infection. It is characterized by alterations of alveolar epithelium, proliferation of fibroblasts, accumulation of components of the extracellular matrix and thickening of the alveolar walls [1-3]. Pulmonary fibrosis is the major side-effect of the antineoplastic agent bleomycin. Intratracheal administration of bleomycin into the lung of rats is frequently used for induction of experimental lung fibrosis [1, 3-12].

Proteoglycans consisting of glycosaminoglycan chains covalently attached to a core protein are major components of the nonfibrillar part of the extracellular matrix filling the space between the fibrous proteins. They modulate cellular adhesion, proliferation and cell migration [13]. In the distal parts of the lung, proteoglycans are important for the structural integrity of the alveolar wall $[14,15]$. In the alveolar interstitium, fibroblasts are the predominant source of proteoglycans [16-18].

There are several lines of evidence suggesting involvement of altered proteoglycan deposition in the development of lung diseases, such as adult respiratory distress syndrome [17, 19], sarcoidosis
[20], bronchiolitis obliterans [17, 21], extrinsic allergic alveolitis [20], tuberculosis [20], or idiopathic pulmonary fibrosis [20, 22]. In bleomycin-induced lung injury in the rat or hamster, accumulation of hyaluronan was described as preceding pulmonary fibrosis $[4,5,23,24]$.

The small proteoglycans decorin and biglycan, which contain chondroitin sulphate or dermatansulphate chains, bind to dermal elastic fibres [25]. Decorin is found closely associated with collagen in the lung [26] and it may play a role in the regulation of collagen fibrillogenesis $[27,28]$. Both decorin and biglycan are able to bind transforming growth factor (TGF)- $\beta$ and to inactivate it [29-32], giving rise to the hope of using decorin to decrease excessive levels of free TGF- $\beta$ observed in lung fibrosis [11]. WESTERGREN-THORSSON et al. [33] reported increased messenger ribonucleic acid (mRNA) levels and proteoglycan amounts for biglycan, and an opposite pattern for decorin in bleomycin-induced fibrosis in rats. It was suggested that versican, a large chondroitin sulphate proteoglycan (CSPG), forms a provisional matrix for collagen deposition in areas of developing pulmonary fibrosis [17, 20].

An important step for the formation of most of the 
polysaccharide side chains of connective tissue proteoglycans, is the transfer of D-xylose from UDPxylose to certain serine residues of proteoglycan core proteins by UDP-D-xylose: core protein $\beta$-D-xylosyltransferase (UDP-xylosyltransferase; EC 2.4.2.2.6). This enzyme initiates a series of post-translational modifications necessary for transport and secretion of proteoglycans [34].

This study describes the localization and increased deposition of chondroitin sulphate proteoglycans in the alveolar region of bleomycin-induced lung injury. The time course of changes in the proteoglycan deposition and in the activity of xylosyltransferase in lung tissue and in lung fibroblasts was investigated.

\section{Materials and methods}

\section{Animals, bleomycin administration and tissue prepara-} tion

Female rats of a Wistar strain, weighing $200 \mathrm{~g}$, received under ketamine anesthesia, a single dose of 7.5 units bleomycin sulphate $\mathrm{kg}^{-1}$ body weight (Mack, Illertissen, Germany) dissolved in $0.25 \mathrm{~mL}$ of $0.9 \% \mathrm{NaCl}$ solution, by endotracheal instillation as described previously [12]. Controls received an equal volume of the vehicle. The animals were sacrificed at given times and the lungs were flushed free of blood across the right ventricle with phosphate-buffered saline (PBS), pH 7.4, containing $50 \mathrm{U}$ heparin $\cdot \mathrm{mL}^{-1}$.

Lung tissue was minced in two volumes of $100 \mathrm{mM}$ Tris/ $\mathrm{HCl}$, pH 7.0, containing $250 \mathrm{mM} \mathrm{NaCl}, 1 \mathrm{mM}$ ethylenediaminetetraacetic acid (EDTA), $5 \mathrm{mM}$ benzamidine hydrochloride, $2 \mathrm{mM}$ iodoacetic acid and $1 \mu \mathrm{M}$ soybean trypsin inhibitor. After homogenization with a motor driven teflon pestle, the homogenate was centrifuged at $100,000 \times g$ at $4^{\circ} \mathrm{C}$ for $1 \mathrm{~h}$. The supernatant was dialysed against $50 \mathrm{mM}$ Tris/ $\mathrm{HCl}$, $\mathrm{pH} 7.0$, containing $50 \mathrm{mM} \mathrm{NaCl}$.

For immunohistochemical studies, lungs were fixed by immersion in 4\% phosphate-buffered formalin and embedded in paraffin as described earlier [35]. The time course of bleomycin-induced changes in CSPG and versican distribution was followed by examination of lungs fixed $7,14,21,28,35$, or 42 days after treatment $(n=2)$. Control lungs were obtained from two untreated animals. To evaluate bleomycininduced fibrosis, sections of lung tissue were stained with polyclonal rabbit antirat collagen I (Chemicon, Temecula, CA, USA).

\section{Preparation of lung fibroblasts and bleomycin treat- ment}

Fibroblasts from the lungs of 3-month-old female Wistar rats were prepared by enzymic dissociation of lung tissue after vascular perfusion and repeated bronchoalveolar lavage with PBS using $0.2 \%$ collagenase type I (Sigma, Deisenhofen, Germany), 0.15\% pronase (Boehringer, Mannheim), $0.08 \%$ dispase (Boehringer) and 0.9\% DNase (Sigma). The isolated cells were filtered (filter holes $100 \mu \mathrm{m}$ ), collected by centrifugation and resuspended in Roswell Park Memorial Institute (RPMI) 1640 culture medium supplemented with $10 \%$ foetal calf serum (Biochrom, Berlin, Germany), $50 \mathrm{IU}$ penicillin $\cdot \mathrm{mL}^{-1}$ and $50 \mu \mathrm{g}$ streptomycin $\cdot \mathrm{mL}^{-1}$. Cells were passaged routinely and the media were changed every 3 days. Cells between passage numbers 4 and 20 were used for experiments.

For bleomycin treatment, subconfluent lung fibroblasts were deprived of serum for $24 \mathrm{~h}$ and treated with bleomycin for $1 \mathrm{~h}$. The medium was then changed, the cells were kept free of serum for $12 \mathrm{~h}$ and harvested using $0.05 \%$ trypsin with $0.5 \% \mathrm{mM}$ EDTA (Biochrom). Viability was checked by trypan blue exclusion.

For preparation of homogenates, cells were suspended in $100 \mathrm{mM}$ Tris/ $\mathrm{HCl}, \mathrm{pH} \mathrm{7.0,} \mathrm{containing}$ $250 \mathrm{mM} \mathrm{NaCl}, 1 \mathrm{mM}$ EDTA, $5 \mathrm{mM}$ benzamidine hydrochloride, $2 \mathrm{mM}$ iodoacetic acid, $1 \mu \mathrm{M}$ soybean trypsin inhibitor and $0.5 \%$ Triton $\mathrm{X}-100$ with brief sonication. After incubation for $12 \mathrm{~h}$, samples were centrifuged at $100,000 \times g$ at $4^{\circ} \mathrm{C}$ for $1 \mathrm{~h}$, and the supernatant was dialysed against $50 \mathrm{mM}$ Tris $/ \mathrm{HCl}$, $\mathrm{pH} 7.0$ containing $50 \mathrm{mM} \mathrm{NaCl}$ for $12 \mathrm{~h}$.

\section{Determination of UDP-xylosyltransferase activity}

UDP-xylosyltransferase activity was determined as described previously [34]. Briefly, the reaction mixture contained in a final volume of $100 \mu \mathrm{L}: 320 \mu \mathrm{M}$ acceptor peptide of the sequence Q-E-E-E-G-S-G-GG-Q-G-G, $0.46 \mu \mathrm{M}$ UDP- $\left[{ }^{14} \mathrm{C}\right]-\mathrm{D}-\mathrm{xylose}, 68 \mu \mathrm{M}$ UDPD-xylose, $5 \mathrm{mM} \mathrm{MnCl} \mathrm{man}_{2}$ and cell or tissue homogenates. After incubation at $37^{\circ} \mathrm{C}$ for $1 \mathrm{~h}$, protein was precipitated by addition of $0.5 \mathrm{~mL} 10 \%$ trichloroacetic acid $/ 4 \%$ phosphotungstic acid, washed and redissolved in $1 \mathrm{M} \mathrm{NaOH}$ for liquid scintillation counting. Xylosyltransferase activity was calculated from the difference of UDP-D-xylose initially employed and D-xylose bound to the acceptor peptide. One $\mathrm{mU}$ of enzymic activity represents the incorporation of $1 \mathrm{nmol}$ xylose $\cdot \mathrm{min}^{-1}$ into the acceptor peptide. The acceptor peptide was obtained by solid-phase peptide synthesis (9050 PepSynthesizer, MilliGen/Biosearch, Bedford, MA, USA). Protein concentrations were determined according to BRADFORD [36].

\section{Immunoperoxidase staining of proteoglycans}

For immunohistochemical localization of CSPGs, rabbit antichondroitin sulphate proteoglycan antiserum (Bioproducts, Ingelheim, Germany) was used. This antiserum reacts with proteoglycans containing glucuronic acid- $N$-acetyl-galactosamine (GlcUGalNAc) units unmasked by chondroitinase ABC digestion. Versican was detected using anti-full-length human versican antiserum (kindly provided by E. Ruoslahti, Cancer Research Center, La Jolla, CA, USA [37]). The antisera LF-106 against synthetic mouse biglycan peptide and LF-113 against synthetic mouse decorin peptide were the kind gift of L.W. Fisher, NIH, Bethesda, MD, USA [38]. Antisera LF106 and LF-113 are immunoreactive with rat proteoglycans and do not cross-react with each other [39, 40]. 
Paraffin sections were mounted on silane coated slides, dried for $12 \mathrm{~h}$, and dewaxed. Unless stated otherwise, the following steps were performed at $25^{\circ} \mathrm{C}$. Sections to be stained for biglycan and decorin were processed without pretreatment. Tissue sections to be stained for CSPG were microwave-irradiated at $750 \mathrm{~W}$ (twice for $5 \mathrm{~min}$ each) in $10 \mathrm{mM}$ sodium citrate, $\mathrm{pH}$ 6.0. The sections were then incubated in $50 \mathrm{mM}$ Tris/ $\mathrm{HCl}$, pH 8.0, containing $50 \mathrm{mM} \mathrm{NaCl}$ and $0.5 \mu \mathrm{L}$ chondroitinase $\mathrm{ABC} \cdot \mathrm{mL}^{-1}$ from Proteus vulgaris (Sigma), at $37^{\circ} \mathrm{C}$ for $90 \mathrm{~min}$. Dewaxed tissue sections to be stained for versican, and collagen type I were pretreated with $0.1 \%$ pronase (Merck, Darmstadt, Germany) in PBS for 15 min. After blocking of endogenous peroxidase and unspecific antibody binding, tissue sections were incubated with antisera against either CSPG (dilution 1:50), versican (dilution $1: 50$ ), decorin (dilution 1:100), biglycan (dilution $1: 100$ ) or collagen I (dilution 1:50, all dilutions in PBS) at $37^{\circ} \mathrm{C}$ for $1 \mathrm{~h}$. For detection of primary antibodies, tissue sections were washed with PBS for $10 \mathrm{~min}$ and incubated with peroxidase-coupled goat antirabbit immunoglobulin-G (IgG) (horse radish peroxidase (HRP)77; H. Grossmann, Dresden, dilution 1:400 in PBS containing 50\% foetal calf serum) for $60 \mathrm{~min}$, followed by incubation with $1.67 \mathrm{mM}$ diaminobenzidine for $8 \mathrm{~min}$. The ABC Vectastain kit (Vector Laboratories Burlingame, CA, USA) was used to visualize the binding of the monoclonal anticollagen I antibody. After rinsing in PBS, counterstaining with haematoxylin was performed. To reduce background staining in the immunohistochemical localization of versican, PBS was supplemented with $0.1 \%$ acetylated bovine serum albumin (Aurion, Köln, Germany). For control of specificity, primary antibodies were replaced by PBS.

\section{Detection of proteoglycans with cationic colloidal gold}

Cationic colloidal gold (CCG) of $12 \mathrm{~nm}$ average diameter was stabilized with poly-L-lysine of $27 \mathrm{kDa}$ molecular mass [41]. For ultrastructural localization of polyanionic proteoglycans, pieces of normal and fibrotic lung tissue were fixed in $0.1 \mathrm{M}$ sodium cacodylate containing $4 \%$ formaldehyde and $0.2 \%$ glutaraldehyde [41, 42]. As described earlier [43], the lungs were infiltrated with PBS containing $2.3 \mathrm{M}$ sucrose, frozen in liquid nitrogen, cryo-substituted with methanol at $-80^{\circ} \mathrm{C}$, embedded in Lowycryl HM20 and polymerized at $-30^{\circ} \mathrm{C}$ in a Reichert AFS (Leica, Hamburg, Germany). Ultrathin sections were mounted on 200 mesh nickel grids precoated with 3\% colloidin. Sections from fibrotic lungs were incubated in $100 \mathrm{mM}$ Tris $/ \mathrm{HCl}, \mathrm{pH} 7.0$, containing $137 \mathrm{mM}$ $\mathrm{NaCl}, 40 \mathrm{mM} \mathrm{CaCl} 2$ and $1 \mathrm{U}$ of heparinase III $\cdot \mathrm{mL}^{-1}$ from Flavobacterium heparinum or in $50 \mathrm{mM}$ Tris/ $\mathrm{HCl}$, pH 8.0, containing $50 \mathrm{mM} \mathrm{NaCl}$ and $1 \mathrm{U}$ chondroitinase $\mathrm{ABC} \cdot \mathrm{mL}^{-1}$ from Proteus vulgaris (Sigma), at $37^{\circ} \mathrm{C}$ for $2 \mathrm{~h}$ and washed thoroughly with PBS. Control sections were incubated with PBS containing $1 \%$ bovine serum albumin for $5 \mathrm{~min}$. All sections were washed with PBS, labelled with CCG (dilution 1:40 in PBS) for $1 \mathrm{~h}$, jet-washed with distilled

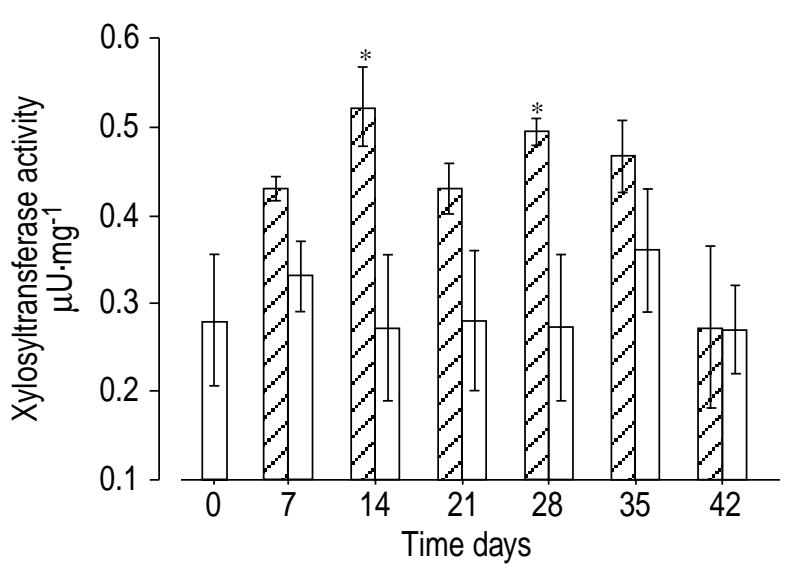

Fig. 1.-Changes in the specific activity of UDP-D-xylose: core protein $\beta$-D-xylosyltransferase (UDP-xylosyltransferase) in lung tissue following intratracheal administration of bleomycin (mean $\pm S D$, $\mathrm{n}=5$ ). $\square$ : lung tissue of controls; $\nabla$ : lung tissue of bleomycintreated rats. *: $\mathrm{p}<0.05$, treated group versus controls, Kruskal-Wallis H-Test.

water, and counterstained with saturated uranyl acetate in $50 \%$ ethanol for $30 \mathrm{~min}$.

\section{Results}

\section{Activities of UDP-xylosyltransferase}

Figure 1 shows the time course of changes in the specific activity of UDP-xylosyltransferase in rat lung tissue following intratracheal bleomycin administration. The activity of the enzyme increased by $\sim 1.6$-fold 7 days after bleomycin treatment and reached a maximum of $\sim 2$-fold of controls at day 14. Xylosyltransferase activity remained at a high level up to 35 days post-bleomycin administration. Thereafter, the level declined and reached control values at day 42 .

Treatment of isolated rat lung fibroblasts with bleomycin for $13 \mathrm{~h}$ resulted in increasing xylosyltransferase activities (fig. 2). The increase of the activity seems to depend on bleomycin concentration,

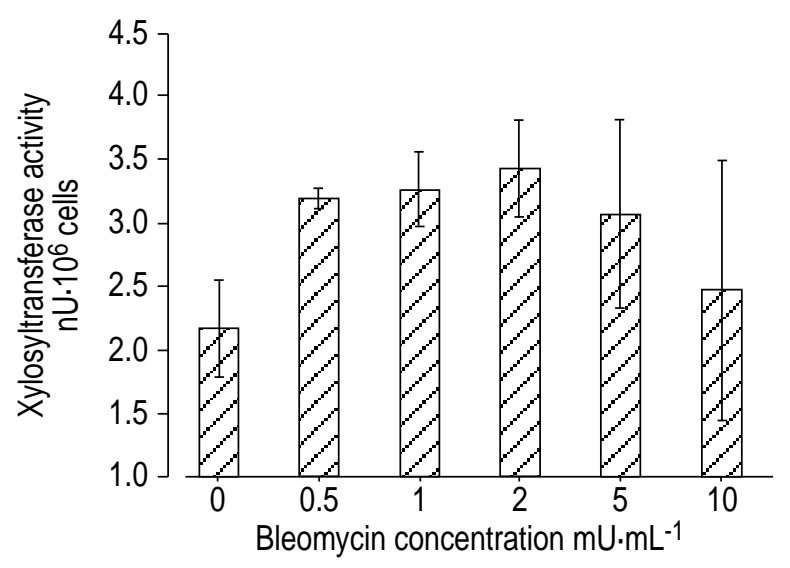

Fig. 2.-Specific activity of UDP-D-xylose: core protein $\beta$-Dxylosyltransferase (UDP-xylosyltransferase) in isolated rat lung fibroblasts treated with bleomycin for $13 \mathrm{~h}($ mean $\pm \mathrm{SD}, \mathrm{n}=3)$. 
however, the differences were not significant. The maximum value of $\sim 1$.6-fold of controls was observed at $2 \mathrm{mU}$ bleomycin $\cdot \mathrm{mL}^{-1}$. At higher concentrations of bleomycin the UDP-xylosyltransferase activity was found at lower levels. Toxic effects of the cytostatic drug may interfere with the stimulatory effect on xylosyltransferase activity.

\section{Immunohistochemical localization of proteoglycans}

CSPG and the individual proteoglycans, versican, biglycan and decorin exhibited distinct distribution patterns in the normal rat lung (table 1). Anti-CSPG immunoreactivity was exclusively extracellular. Staining for CSPG was most prominent in the peribronchial (lamina propria, submucosa) and perivascular (adventitial) interstitium. Except for alveolar entrance rings, alveolar septae exhibited only weak staining of the extracellular matrix (fig. 3a). Anti-versican immunoreaction was restricted to the lamina propria beneath the bronchiolar epithelium and the vascular endothelium, and to the tunica media of vessels, in particular to internal and, where present, external elastic lamina. Only traces of versican were detected in the interstitium of alveolar walls, even at alveolar entrance rings (fig. 3b). Decorin was detected in the connective tissue of the vascular adventitia, whereas for biglycan most prominent staining was associated with the tunica media of pulmonary vessels. Both proteoglycans were detected in the airway epithelium (table 1). There was no staining of any parenchymal component for decorin or biglycan (fig. 3c). Intense immunoreactivity for collagen I occurred in the vascular tunica adventitia and in the lamina propria (fig. 4a, b). Furthermore, the submucosa of airways was stained (fig. 4b), whereas the alveolar parenchyma was lacking of collagen I immunoreactivity (fig. 4c).

In bleomycin-treated rat lungs, CSPG increased with time after treatment (fig. 3d, f, i). This was also accompanied by increasing versican deposition (fig. 3e, g, j). As early as 7 days after treatment, an increase in the parenchymal immunoreactivity for CSPG and for versican, respectively, was observed, particularly at alveolar entrance rings.

The increasing deposition of both CSPG and versican was closely associated with the development of fibrotic alterations at alveolar entrance rings (fig. 3d, e) and an increase in the number of $\alpha$-smooth muscle actin-positive cells at sites of fibrotic lesions was observed. Fibrotic plugs showed prominent staining of the extracellular matrix in proximity to $\alpha$-smooth muscle actin-positive cells for both CSPG and versican (fig. 3j). In contrast, biglycan and decorin did not show any fibrosis-relevant changes, with the exception of the appearance of a weak intracellular staining of alveolar type II pneumocytes and macrophages for decorin (fig. 3h). Deposition of collagen I was observed in the alveolar interstitium at alveolar entrance rings (fig. 4d) and in regions showing thickened alveolar walls (fig. 4e).

\section{Detection of polyanionic components with cationic colloidal gold}

In normal lung tissue, polyanionic components were localized at the basal lamina of the alveolar epithelium, whereas weak labelling was associated with collagen fibrils (fig. 5a). Twenty-eight days after bleomycin treatment, increased labelling of the extracellular matrix with CCG was detected in fibrotic areas of lung tissue, particularly in association with bundles of collagen and elastin fibrils (fig. 5b). To elucidate, if the polyanions associated with fibrous extracellular matrix components are proteoglycans belonging to CSPGs or heparansulphate proteoglycans (HSPGs), ultrathin sections of fibrotic lung tissue were treated with chondroitinase $\mathrm{ABC}$ or heparinase III. No CCG labelling of the collagen bundles was observed after heparinase treatment (fig. 5c, d).

Table 1. - Main sites of immunohistochemical staining for proteoglycans and collagens in normal and fibrotic rat lungs

\begin{tabular}{|c|c|c|c|c|c|}
\hline Region & CSPG & Versican & Biglycan & Decorin & Collagen I \\
\hline \multicolumn{6}{|l|}{ Normal rat lung } \\
\hline \multicolumn{6}{|l|}{ Airways } \\
\hline Epithelium & - & - & + & + & - \\
\hline Lamina propria & ++ & ++ & - & - & ++ \\
\hline Submucosa & ++ & - & - & + & ++ \\
\hline \multicolumn{6}{|l|}{ Vessels } \\
\hline Endothelium & - & - & - & - & - \\
\hline Lamina propria & + & ++ & - & + & + \\
\hline Media & + & + & ++ & - & + \\
\hline Adventitia & ++ & - & + & ++ & ++ \\
\hline \multicolumn{6}{|l|}{ Alveolar walls } \\
\hline Extracellular & ++ & + & - & - & + \\
\hline Intracellular & - & - & - & - & - \\
\hline $\begin{array}{l}\text { Changes associated } \\
\text { with bleomycin-induced } \\
\text { pulmonary fibrosis } \\
\text { in rat }\end{array}$ & $\begin{array}{l}\text { Increased } \\
\text { extracellular } \\
\text { staining in } \\
\text { fibrotic foci }\end{array}$ & $\begin{array}{l}\text { Increased } \\
\text { extracellular } \\
\text { staining in } \\
\text { fibrotic foci }\end{array}$ & $\begin{array}{l}\text { Weak } \\
\text { intracellular } \\
\text { staining } \\
\text { (PII, AM) }\end{array}$ & $\begin{array}{l}\text { Weak } \\
\text { intracellular } \\
\text { staining } \\
\text { (PII, AM) }\end{array}$ & $\begin{array}{l}\text { Increased } \\
\text { extracellular } \\
\text { staining }\end{array}$ \\
\hline
\end{tabular}

-: no staining; +: weak staining; ++: prominent staining; CSPG: Chondroitinsulphate proteoglycan; PII: alveolar type II pneumocytes; AM: alveolar macrophages. 

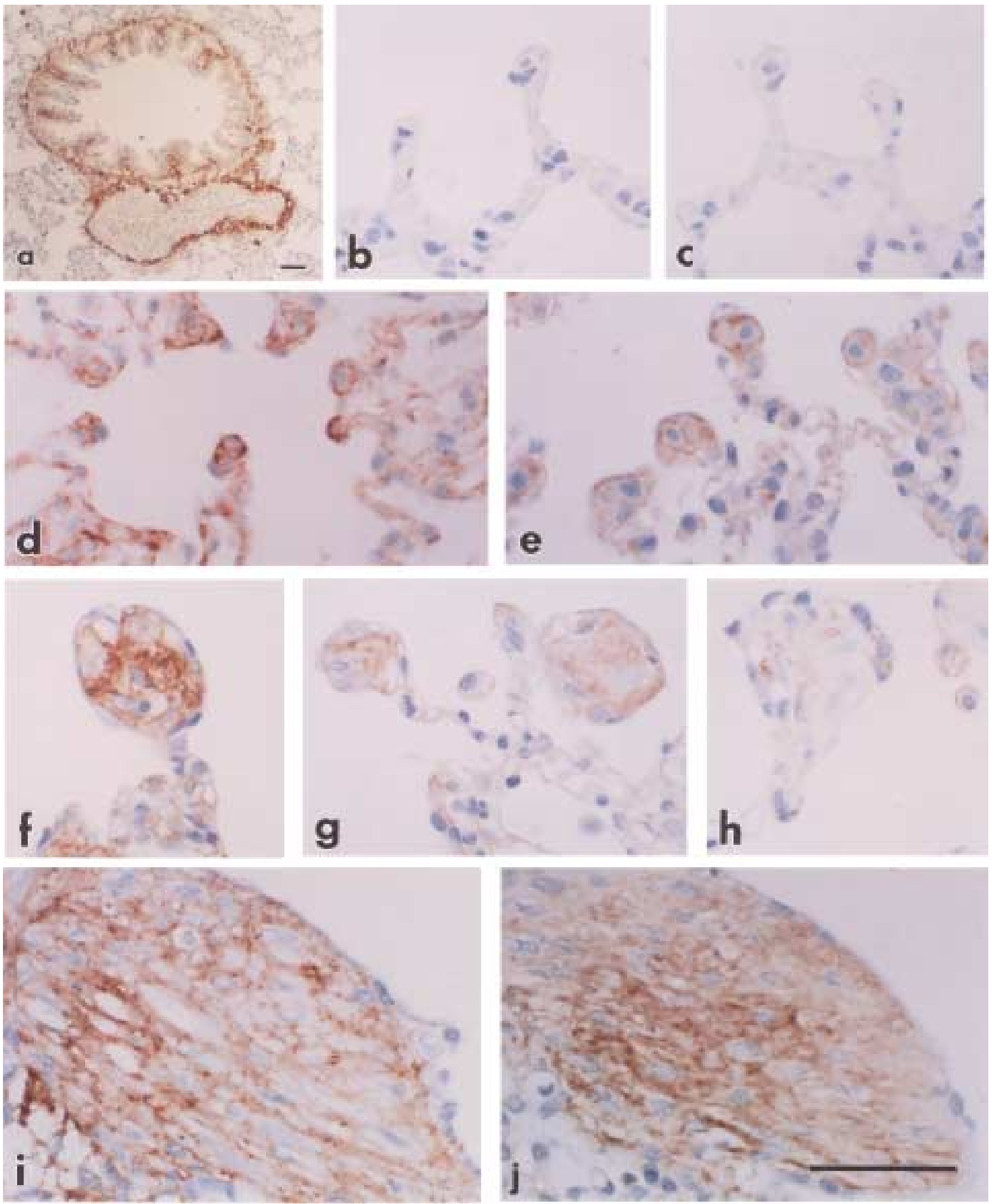

Fig. 3. - Localization of proteoglycans in normal $(a-c)$ and in fibrotic $(d-j)$ rat lung. Chondroitinsulphate proteoglycan (CSPG) (a, d, f, i), versican $(b, e, g, j)$ and decorin $(c, h)$ at days $7(d, e), 14(f-h)$ and $28(i, j)$ following bleomycin administration. Note the staining for CSPG at alveolar entrance rings in normal lung tissue (a), whereas no versican (b) or decorin (c) was detected in alveolar parenchyma. Increased amounts of CSPG (a, d, f, i) and versican (b, e, g, j), respectively, were found in the extracellular matrix. For decorin, an increase in intracellular staining was detected $(\mathrm{c}, \mathrm{h})$. Scale bars $=50 \mu \mathrm{m}$. 

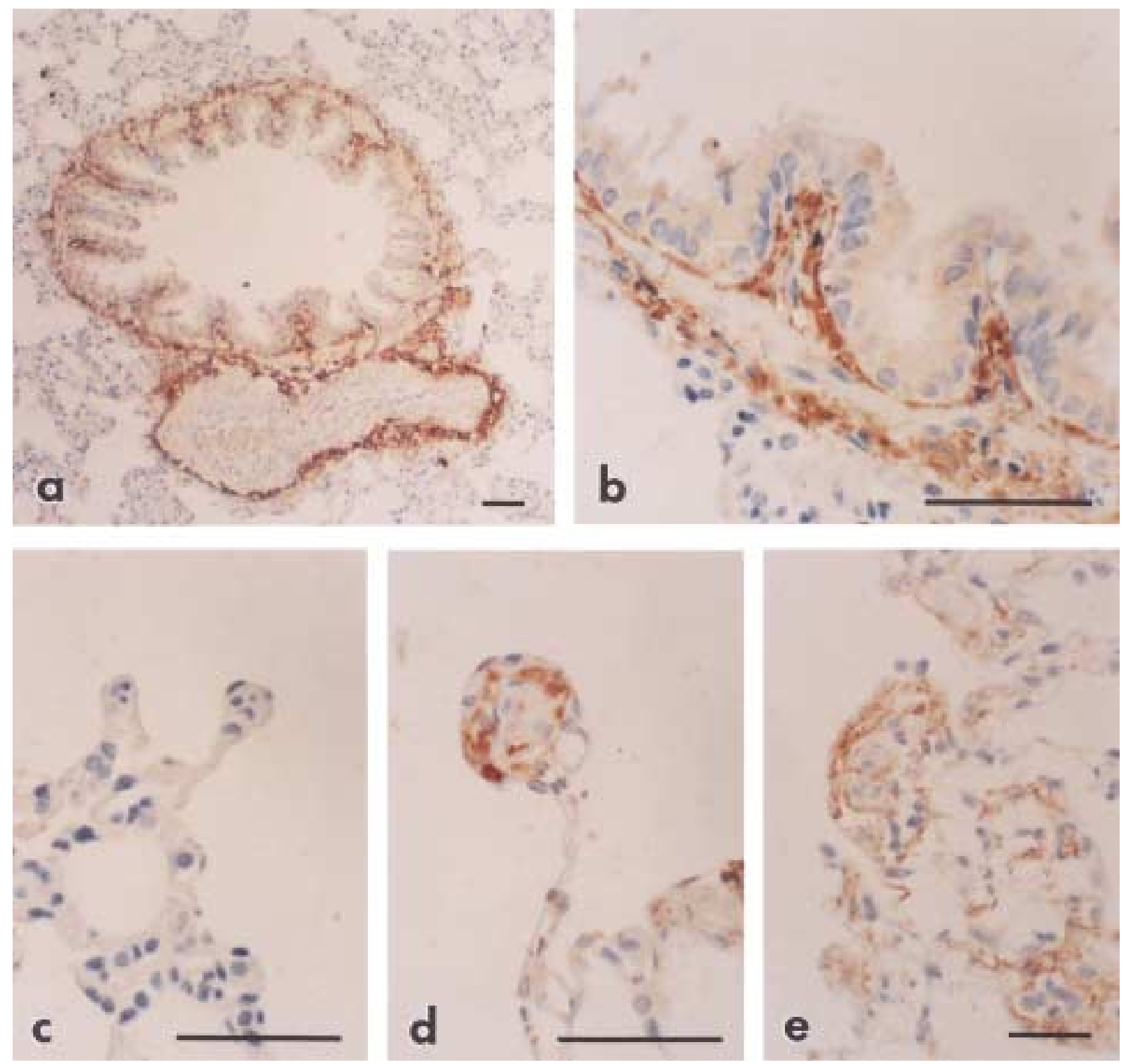

Fig. 4. - Localization of collagen I in normal $(\mathrm{a}-\mathrm{c})$ and fibrotic $(\mathrm{d}$, e) rat lung tissue at day 35 following intratracheal bleomycin administration. In normal rat lung, intense staining is associated with vascular tunica adventitia and lamina propria as well as submucosa of airways (a, b), whereas parenchyma shows no collagen I immunoreactivity (c). Bleomycin treatment resulted in an increase of collagen I at alveolar entrance rings and in fibrotic foci $(\mathrm{d}, \mathrm{e})$. Scale bars $=50 \mu \mathrm{m}$.

Treatment with chondroitinase $\mathrm{ABC}$ did not result in any reduction of CCG labelling of collagen fibrils (data not shown).

\section{Discussion}

The results presented in this study demonstrate coincidence of increasing catalytic activities of UDPxylosyltransferase with increasing deposition of CSPG in general, and of versican as an individual CSPG in fibrotic regions of rat lungs following intratracheal bleomycin administration.

Proteoglycans consist of a core protein and glycosaminoglycan side chains. UDP-xylosyltransferase catalyzes the transfer of D-xylose from UDP-Dxylose to certain serine residues in the core proteins of proteoglycans as a rate-limiting step for glycosylation. There have been several potential attachment sites for glycosaminoglycan side chains reported for the versican core protein $[13,37]$. The assembly of the entire molecule depends on the synthesis of the core protein and on the velocity of the glycosylation.

The increased immunoreactivity for versican observed at alveolar entrance rings and in fibrotic foci in bleomycin-injured rat lungs may be a sign for elevated core protein synthesis regardless of glycosylation, because the antiserum against versican 

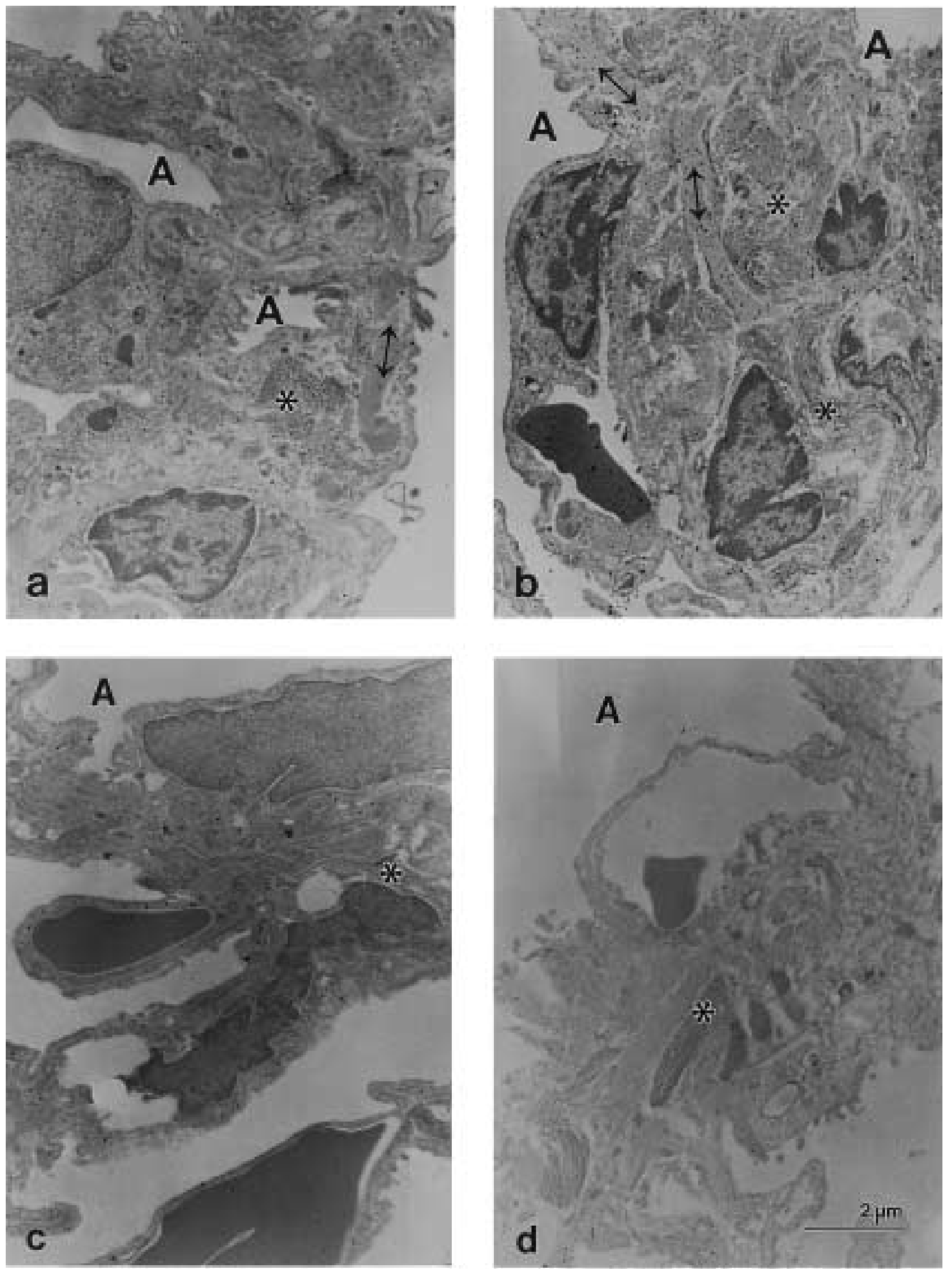

Fig. 5. - Localization of polyanionic compounds in normal (a) and fibrotic rat lung at day 28 following intratracheal bleomycin administration (b-d). Polyanions were detected by cationic gold labelling and evaluated by electron microscopy. In normal lung (a) and normal appearing lung tissue of bleomycin-treated lung (c), cationic colloidal gold (CCG) was predominantly associated with basal membranes of the air blood-barrier. In fibrotic foci of the bleomycin-treated lung (b), an increase in CCG associated with collagen bundles $(*)$ and elastic fibres (double-headed arrows) was observed, which was abolished by pretreatment of ultrathin sections with heparinase III (d). A: air space. Scale bar=2 $\mu \mathrm{m}$. 
recognizes the core protein. Anti-CSPG antiserum reacts with GlcU-GalNAc units unmasked by chondroitinase $\mathrm{ABC}$ digestion and, therefore, detects all CSPGs. The colocation of CSPG and versican observed in fibrotic areas of injured lung tissue indicates that a considerable fraction of the CSPG detected in these regions represents glycosylated versican, although the number of glycosaminoglycan side chains is unknown. Increased glycosylation of the core protein alone does not explain the increase in immunoreactivity for versican. At minimum, a coordinated regulation of both core protein synthesis and xylosyltransferase activity ensures the accumulation of the entire proteoglycan. After bleomycin administration, elevated catalytic activies of xylosyltransferase were found in injured lung tissue, accompanied by increased deposition of CSPG and versican. Bleomycin treatment of isolated lung fibroblasts resulted in concentration-dependent changes in xylosyltransferase activity. At low bleomycin concentrations, enzymic activity increased slightly, whereas at bleomycin concentrations $>5 \mathrm{mU} \cdot \mathrm{mL}^{-1}$, xylosyltransferase activity was found decreased, probably due to toxic effects of bleomycin on the cells. UDP-xylosyltransferase was recently purified from rat ear cartilage and some properties were studied [34]. So far, nothing is known about the regulation of the biosynthesis of this transferase. KäHÄRI et al. [44] reported that in human fibroblasts TGF- $\beta_{1}$ upregulates versican and biglycan mRNA synthesis, and downregulates decorin mRNA synthesis [44]. LiU et al. [45] reported on platelet-derived growth factor (PDGF)-BB-induced stimulation of sulphate incorporation into biglycan without affecting the biglycan core protein mRNA level. TGF- $\beta$ and PDGF seem to be candidates involved in the regulation of xylosyltransferase.

Accumulation of versican starts in the interstitium of alveolar entrance rings. In the alveolar septa, myofibroblasts sharing morphologic and biochemical features of both fibroblasts and smooth muscle cells are prominent $[46,47]$. At the tips of alveolar septa, a smooth muscle cell-type predominates. $\alpha$-Smooth muscle actin is a reliable differentiation marker of myofibroblasts, but it does not allow differentiation between myofibroblasts and smooth muscle cells. Rat alveolar fibroblasts acquire $\alpha$-smooth muscle actin as early as $24 \mathrm{~h}$ after intratracheal instillation of bleomycin, and these myofibroblasts are the predominant cells at sites of active fibrosis in the bleomycininjured lung where they synthesize $\alpha_{1}(\mathrm{I})$ procollagen $[9,10,44,47-49]$. The present data suggest that the versican deposition at the septal tips is a result of increased synthesis by smooth muscle cells, as was shown by WIGHT et al. [13], whereas myofibroblastlike cells represent the source of versican in fibrotic foci. Close association of versican and collagen I with myofibroblasts in the extracellular matrix of fibrotic plugs of rat lung, as shown here, confirms the data presented by BENSADOUN et al. [17] on accumulation of versican in early fibrotic foci of idiopathic pulmonary fibrosis and in granulomatous lung diseases in humans [20]. The deposition of versican precedes the accumulation of collagen in the alveolar interstitium, suggesting versican is a constituent of a provisional matrix influencing functions of myofibroblasts embedded in this matrix [17, 20].

The present results are partly in contrast to the report of WeSTERGREN-THORSSON et al. [33] who described increased biglycan levels and decreased decorin levels in bleomycin-induced lung fibrosis in rat. However, in their study [33], mRNA levels and proteoglycan amounts were determined after extraction and purification of proteoglycans. VENESS-MEEHAN and coworkers $[50,51]$ reported on immunohistochemical detection of biglycan and decorin in lungs of newborn Sprague-Dawley rats exposed to hyperoxia. The present study's results confirm the reports on decorin core protein detection surrounding blood vessels and immunoreactivity for both biglycan and decorin in association with airways [50, 51]. In 6-week-old control animals, Veness-MeEhan et al. [50] showed an overall decrease of immunostaining for biglycan. The present study used 3-month-old Wistar rats and the difference in age, and probably in rat strain, may explain the lack of staining of alveolar epithelium and of alveolar walls in the present study.

Taken together, the data suggest that the deposition of versican is an early event throughout the development of bleomycin-induced pulmonary fibrosis, followed by accumulation of collagen at the same location where myofibroblasts predominate. The coincidence of the increase of UDP-D-xylose: core protein $\beta$-D-xylosyltransferase activity with the accumulation of versican supports the hypothesis of a coordinated regulation of the synthesis of both xylosyltransferase and proteoglycans.

Acknowledgements. The authors wish to thank P. Peche, I. Peterson and A. Hientzsch for excellent technical assistance.

\section{References}

1. Lazenby AJ, Crouch EC, McDonald JA, Kuhn C. Remodeling of the lung in bleomycin-induced pulmonary fibrosis in the rat. Am Rev Respir Dis 1990; 142: 206-214.

2. Kasper M, Koslowski R, Luther T, Schuh D, Müller $\mathrm{M}$, Wenzel K-W. Immunohistochemical evidence for loss of ICAM-1 adhesion molecule by alveolar epithelial cells in pulmonary fibrosis. Histochem Cell Biol 1995; 104: 397-405.

3. Koslowski R, Dobbs LG, Wenzel K-W, Schuh D, Müller M, Kasper M. Loss of immunoreactivity for RTI40, a type I cell-specific protein in the alveolar epithelium of rat lung with bleomycin-induced fibrosis. Eur Respir J 1998; 12: 1397-1403.

4. Bray BA, Sampson PM, Osman M, Giandomenico A, Turino GM. Early changes in lung tissue hyaluronan (hyaluronic acid) and hyaluronidase in bleomycininduced alveolitis in hamsters. Am Rev Respir Dis 1991; 143: 284-288.

5. Hernnäs J, Nettelbladt O, Bjermer L, Särnstrand B, Malmström A, Hallgren R. Alveolar accumulation of fibronectin and hyaluronan precedes bleomycininduced pulmonary fibrosis in the rat. Eur Respir $J$ 1992; 5: 404-410. 
6. Khalil N, Whitman C, Zuo L, Danielpour D, Greenberg A. Regulation of alveolar macrophage transforming growth factor- $\beta$ secretion by corticosteroids in bleomycin-induced pulmonary inflammation in the rat. J Clin Invest 1993; 92: 1812-1818.

7. Shahzeidi S, Jeffery PK, Laurent GJ, McAnulty RJ. Increased type I procollagen mRNA transcripts in the lungs of mice during the development of bleomycininduced fibrosis. Eur Respir J 1994; 7: 1938-1943.

8. Zhang K, Rekhter MD, Gordon D, Phan SH. Myofibroblasts and their role in lung collagen gene expression during pulmonary fibrosis. Am J Pathol 1994; 145: 114-125.

9. Zhang K, Gharaee-Kermani M, McGarry B, Phan SH. In situ hybridization analysis of rat lung $\alpha_{1}(\mathrm{I})$ and $\alpha_{2}(\mathrm{I})$ collagen gene expression in pulmonary fibrosis induced by endotracheal bleomycin injection. Lab Invest 1994; 70: 192-202.

10. Zhang H-Y, Gharaee-Kermani M, Zhang K, Karmiol $\mathrm{S}$, Phan SH. Lung fibroblast $\alpha$-smooth muscle actin expression and contractile phenotype in bleomycininduced pulmonary fibrosis. Am J Pathol 1996; 148: 527-537.

11. Giri SN, Hyde DM, Braun RK, Gaarde W, Harper JR, Pierschbacher MD. Antifibrotic effect of decorin in a bleomycin hamster model of lung fibrosis. Biochem Pharmacol 1997; 54: 1205-1216.

12. Koslowski R, Knoch K-P, Wenzel K-W. Proteinases and proteinase inhibitors during the development of pulmonary fibrosis in rat. Clin Chim Acta 1998; 271: 45-56.

13. Wight TN, Heinegard DK, Hascall VC. Proteoglycans: structure and function. In: Hay ED, ed. Cell Biology of the Extracellular Matrix, 2nd ed. New York, Plenum Press, 1991; pp. 45-71.

14. Negrini D, Passi A, de Luca G, Miserocchi G. Proteoglycan involvement during development of lesional pulmonary edema. Am J Physiol Lung Cell Mol Physiol 1998; 274: L203-L211.

15. Passi A, Negrini D, Albertini R, de Luca G, Miserocchi G. Involvement of lung interstitial proteoglycans in development of hydraulic- and elastaseinduced edema. Am J Physiol Lung Cell Mol Physiol 1998; 275: L631-L635.

16. McGowan SE, Liu R, Harvey CS. Effects of heparin and other glycosaminoglycans on elastin production by cultured neonatal rat lung fibroblasts. Arch Biochem Biophys 1993; 302: 322-331.

17. Bensadoun ES, Burke AK, Hogg JC, Roberts CR. Proteoglycan deposition in pulmonary fibrosis. $\mathrm{Am}$ J Respir Crit Care Med 1996; 154: 1819-1828.

18. Caniggia I, Liu J, Maciej M, Tanswell AK, Post M. Fetal lung fibroblasts selectively down-regulate proteoglycan synthesis in response to elevated oxygen. J Biol Chem 1996; 271: 6625-6630.

19. Tomashefski JF. Pulmonary pathology of adult respiratory distress syndrome. Clin Chest Med 1990; 11: 593-619.

20. Bensadoun ES, Burke AK, Hogg JC, Roberts CR. Proteoglycans in granulomatous lung diseases. Eur Respir J 1997; 10: 2731-2737.

21. Katzenstein AA, Myers JL, Prophet WD, Corley LS, Shin MS. Bronchiolitis obliterans and usual interstitial pneumonia: a comparative clinicopathological study. Am J Surg Pathol 1986; 10: 373-381.

22. Bjermer L, Lundgren R, Hallgren R. Hyaluronan and type III procollagen peptide concentrations in bronchoalveolar lavage fluid in idiopathic pulmonary fibrosis. Thorax 1989; 44: 126-131.

23. Nettelbladt O, Bergh J, Schenholm M, Tengblad A, Hallgren R. Accumulation of hyaluronic acid in the alveolar interstitial tissue in bleomycin-induced alveolitis. Am Rev Respir Dis 1989; 139: 759-762.

24. Nettelbladt O, Hallgren R. Hyaluronan (hyaluronic acid) in bronchoalveolar lavage fluid during the development of bleomycin-induced alveolitis in the rat. Am Rev Respir Dis 1989; 140: 1028-1032.

25. Baccarani-Contri M, Vincenzi D, Cicchetti F, Mori G, Pasquali-Ronchetti T. Immunocytochemical localization of proteoglycans within normal elastin fibres. Eur J Cell Biol 1990; 53: 305-312.

26. van Kuppevelt TH, van de Lest CHA, Versteeg EMM, Deckhuijzen PNR, Veerkamp VH. Induction of emphysematous lesions in rat lung by $\beta$-D-xyloside, an inhibitor of proteoglycan synthesis. Am $J$ Respir Cell Mol Biol 1997; 16: 75-84.

27. Hedbom E, Heinegard D. Interaction of a $59 \mathrm{kDa}$ connective tissue matrix protein with collagen I and collagen II. J Biol Chem 1989; 264: 6898-6905.

28. Sini P, Denti A, Tira E, Balduini C. Role of decorin on in vitro fibrillogenesis of type I collagen. Glycoconjugate $J$ 1997; 14: 871-874.

29. Yamaguchi Y, Mann DM, Ruoslahti E. Negative regulation of transforming growth factor- $\beta$ by the proteoglycan decorin. Nature 1990; 346: 281-284.

30. Ruoslahti E, Yamaguchi Y, Hildebrand A, Border WA. Extracellular matrix/growth factor interactions. Cold Spring Harb Symp Quant Biol 1992; 57: 309-316.

31. Hildebrand AM, Romaris M, Rasmussen LM, et al. Interaction of the small interstitial proteoglycans biglycan, decorin and fibromodulin with transforming growth factor $\beta$. Biochem $J$ 1994; 302: 527-534.

32. Zhao J, Sime PJ, Bringas P, Gauldie J, Warburton D. Adenovirus-mediated decorin gene transfer prevents TGF- $\beta$-induced inhibition of lung morphogenesis. Am J Physiol Lung Cell Mol Physiol 1999; 277: L412L422.

33. Westergren-Thorsson G, Hernnäs J, Särnstrand B, Oldberg A, Heinegard D, Malmström A. Altered expression of small proteoglycans, collagen, and transforming growth factor- $\beta 1$ in developing bleomycininduced pulmonary fibrosis in rats. J Clin Invest 1993; 92: 632-637.

34. Pfeil U, Wenzel K-W. Purification and some properties of UDP-xylosyltransferase of rat ear cartilage. Glycobiology 2000; 10: 803-807.

35. Kasper M, Sakai K, Koslowski R, et al. Localization of surfactant protein A (SP-A) in alveolar macrophage subpopulations of normal and fibrotic rat lung. Histochemistry 1994; 102: 345-352.

36. Bradford MM. A rapid and sensitive method for the quantitation of microgram quantities of protein utilizing the principle of protein-dye binding. Anal Biochem 1976; 72: 248-254.

37. LeBaron RG, Zimmermann DR, Ruoslahti E. Hyaluronate binding properties of versican. $J$ Biol Chem 1992; 267: 10003-10010.

38. Fisher LW, Stubbs JT, Young MF. Antisera and cDNA probes to human and certain animal model bone matrix noncollagenous proteins. Acta Orthop Scand 1995; 66: Suppl. 266, 61-65.

39. Fisher LW, Hawkins GR, Tuross N, Termine JD. Purification and partial characterization of small proteoglycans I and II, bone sialoproteins I and II, 
and osteonectin from the mineral compartement of developing human bone. J Biol Chem 1987; 262: 9702 9708.

40. Fisher LW, Termine JD, Young MF. Deduced protein sequence of bone small proteoglycan I (biglycan) shows homology with proteoglycan II (Decorin) and several nonconnective tissue proteins in a variety of species. J Biol Chem 1989; 264: 4571-4576.

41. Skutelsky E, Roth J. Cationic colloidal gold - a new probe for the detection of anionic cell surface sites by electron microscopy. J Histochem Cytochem 1986; 34 : 693-696.

42. Weinstein T, Gaiter U, Chagnac A, Skutelsky E. Distribution of proteoglycans in rat renal tubular epithelium. J Am Soc Nephrol 1997; 8: 586-595.

43. Kasper M, Huber O, Grossmann H, Rudolph B, Tränkner C, Müller M. Immunohistochemical distribution of E-cadherin in normal and injured lung tissue of the rat. Histochem Cell Biol 1995; 104: 383390.

44. Kähäri V-M, Larjva H, Uitto J. Differential regulation of extracellular matrix proteoglycan (PG) gene expression. J Biol Chem 1991; 266: 10608-10615.

45. Liu J, Fitzli D, Liu M, et al. PDGF-induced glycosaminoglycan synthesis is mediated via phosphatidylinositol 3-kinase. Am J Physiol Lung Cell Mol Physiol 1998; 274: L702-L713.

46. Weibel ER, Crystal RG. Structural Organization of the Pulmonary interstitium. In: Crystal RG, West JB, eds. The Lung. New York, Raven Press, 1991; pp. 369-380.

47. Leslie KO, Mitchell J, Low R. Lung myofibroblasts. Cell Motil Cytoskeleton 1992; 22: 92-98.

48. Vyalov SL, Gabbiani G, Kapanci Y. Rat alveolar myofibroblasts acquire $\alpha$-smooth muscle actin expression during bleomycin-induced pulmonary fibrosis. Am J Pathol 1993; 143: 1754-1765.

49. Phan SH, Zhang K, Zhang HY, Gharee-Kermani M. The myofibroblast as an inflammatory cell in pulmonary fibrosis. Curr Top Pathol 1999; 93: 173-182.

50. Veness-Meehan KA, Rhodes DN, Stiles AD. Temporal and spatial expression of biglycan in chronic oxygen-induced lung injury. Am J Respir Cell Mol Biol 1994; 11: 509-516.

51. Veness-Meehan KA, Moats-Staats BM, Maniscalco WM, Watkins RH, Stiles AD. Changes in decorin expression with hyperoxic injury to developing rat lung. Pediatr Res 1997; 41: 464-472. 